\title{
Alternatif Pemilihan Laptop Bagi Mahasiswa Di Jakarta Utara Menggunakan Metode Analytic Hierarchy Process
}

\author{
Refael Elnatan ${ }^{1}$ Hendy Tannady $2^{2}$ \\ ${ }^{1}$ Program Studi Teknik Industri, Universitas Bunda Mulia, Indonesia \\ ${ }^{2}$ Program Studi Manajemen, Universitas Pembangunan Jaya, Indonesia \\ Email: elnatanrefael@gmail.com, hendytannady@yahoo.com
}

\begin{abstract}
Laptops are thing that are needed by the community in educational activities and in work activities, but the accuracy in choosing laptops based on needs is difficult because there are many laptop brands with a variety of prices and features. This study discusses the selection of laptops as a daily driver for students in North Jakarta, research using the AHP method to analyze several alternatives that have been determined based on filling priority weights between criteria and criteria, and alternatives with alternatives for each criterion. The results of this study indicate that the price, processor, and RAM criteria are the three biggest criteria determining laptop selection. The alternative chosen in this study is the ASUS A456URKeywords: laptop, bobot prioritas, AHP
\end{abstract}

Keywords: laptop, priority weights, AHP

\begin{abstract}
Abstrak
Laptop merupakan benda yang dibutuhkan oleh masyarakat dalam kegiatan pendidikan maupun dalam kegiatan kerja, namun ketepatan dalam pemilihan laptop berdasarkan kebutuhan merupakan hal yang sulit dikarenakan banyaknya merek laptop dengan berbagai variasi harga dan fitur. Penelitian ini membahas tentang pemilihan laptop sebagai daily driver bagi mahasiswa di Jakarta Utara, penelitian menggunakan metode AHP untuk menganalisis beberapa alternatif yang telah ditentukan berdasarkan pengisian bobot prioritas perbandingan antara kriteria dengan kriteria, dan alternatif dengan alternatif pada masing-masing kriteria. Hasil dari penelitian ini menunjukkan bahwa kriteria harga, processor, dan RAM merupakan tiga kriteria terbesar penentu pemilihan laptop. Alternatif yang terpilih dalam penelitian ini adalah ASUS A456UR.
\end{abstract}

Kata kunci: laptop, bobot prioritas, AHP

\section{Pendahuluan}

Dewasa ini produktivitas merupakan faktor penentu daya saing bagi suatu organisasi (Rahayu et al., 2018; Rahayu et al., 2019). Produktivitas individu dalam sebuah organisasi sangat memengaruhi performa dari organisasi tersebut (Tannady \& Sitorus, 2017). Dengan fasilitas kerja yang baik seorang dapat meningkatkan motivasi (Gabriella \& Tannady, 2019) dan performa kerjanya (Tannady et al., 2019). Performa kerja yang baik juga akan berdampak pada hasil kerja yaitu kepuasan yang dirasakan oleh pelanggan (Tanuwijaya \& Tannady, 2019). Salah satu alat yang dapat membantu dalam meningkatkan produktivitas adalah laptop. Patterson et al. (2017) menyatakan bahwa laptop memiliki potensi dalam meningkatkan produktivitas dalam pendidikan secara drastis dengan melibatkan siswa melalui perangkat lunak berbasis pendidikan, pembuatan tugas lebih banyak dan penyelesaian secara cepat, serta lebih terorganisir dan jangkauan internet untuk mengakses sumber-sumber pembelajaran. Laptop sudah menjadi benda yang dibutuhkan oleh masyarakat dalam kegiatan pendidikan maupun dalam kegiatan kerja, namun ketepatan dalam pemilihan laptop berdasarkan kebutuhan merupakan hal yang sulit dikarenakan banyaknya merek laptop dengan berbagai variasi harga dan fitur (Saragih, 2013).

Hal tersebut pun terjadi pada mahasiswa-mahasiswa yang melanjutkan studi di jenjang strata satu di Jakarta Utara, dimana mahasiswa aktif dalam menggunakan laptop untuk mengerjakan tugas dan penelitian, tetapi produktivitas dari pengerjaan tugas dan penelitian menggunakan laptop dapat meningkat jika laptop yang digunakan sesuai dengan kebutuhan dari tugas dan penelitian tersebut. Software yang digunakan mahasiswa dalam pengerjaan tugas menuntut performa yang cukup tinggi, serta lamanya waktu pengerjaan tugas dan penelitian memerlukan dukungan dari laptop yang nyaman dan tahan lama.

Namun berdasarkan survei yang dilakukan pada mahasiswa-mahasiswa yang berkuliah di Jakarta Utara, terdapat $58,06 \%$ mahasiswa yang merasa tidak puas dengan laptop miliknya untuk mengerjakan tugas, dan 53,33\% mahasiswa merasa kesulitan dalam menentukan laptop sebagai daily driver mereka untuk mengerjakan tugas dan keperluan lainnya.

Oleh karena itu, diperlukan tool yang dapat membantu mempermudah pengambilan keputusan dalam pemilihan laptop sebagai daily driver bagi mahasiswa untuk mengerjakan tugas dan keperluan lainnya. Salah satu tool yang dapat digunakan dalam membantu mempermudah pengambilan keputusan adalah AHP (Analytical Hierarchy Process). 
Menurut Sunarsa \& Handayani (2016) AHP dapat membantu mendapatkan hasil pengambilan keputusan dari permasalahan yang kompleks menjadi sederhana karena adanya hirarki. Sehingga cocok jika digunakan pada kasus penelitian ini, dimana variasi yang sangat luas dari harga dan fitur pada berbagai merek laptop dapat dibandingkan dengan cara yang sederhana.

Tujuan dari penelitian ini adalah menghitung bobot prioritas dari setiap kriteria yang telah ditentukan, menghitung bobot prioritas total dari setiap alternatif setelah dikalikan dengan bobot kriteria dan menganalisa hasil pengambilan keputusan pemilihan laptop menggunakan metode AHP.

\section{AHP (Analytical Hierarchy Process)}

Menurut Saragih (2013) sistem pendukung keputusan merupakan sebuah alternatif solusi/tindakan dari berbagai solusi/tindakan yang bermanfaat dalam menyelesaikan suatu permasalahan dengan efektif dan efisien. AHP (Analytical Hierarchy Process) mampu memecahkan masalah yang rumit seperti kondisi tidak terstruktur menjadi komponen-komponen penyusun hirarki yang diberikan penilaian secara numerik mengenai perbandingan variabel dengan pertimbangan secara subjektif untuk memperoleh prioritas tertinggi (Sunarsa \& Handayani, 2016; Rosta \& Tannady, 2013).

Saaty \& Vargas (2012, p.3) menyatakan bahwa AHP adalah teori umum tentang pengukuran yang digunakan untuk menghasilkan skala rasio dari perbandingan berpasangan berbentuk diskrit maupun kontinu dalam struktur hirarki tingkat berganda. AHP memberikan manfaat dalam pengambilan keputusan untuk memilih alternatif terbaik berdasarkan kriteria tertentu. Menurut Chin et al. (1999) yang dikutip oleh Zaim et al. (2012), AHP tidak hanya menganalisa pengambilan keputusan terbaik saja, tetapi juga menyediakan alasan rasional terhadap pilihan yang dibuat.

Hirarki sederhana terdiri dari 3 tingkat, yaitu: (1) Tingkat pertama tujuan dari pengambilan keputusan, (2) Tingkat kedua kriteria penentu, (3) Tingkat ketiga alternatif yang dapat dipilih.

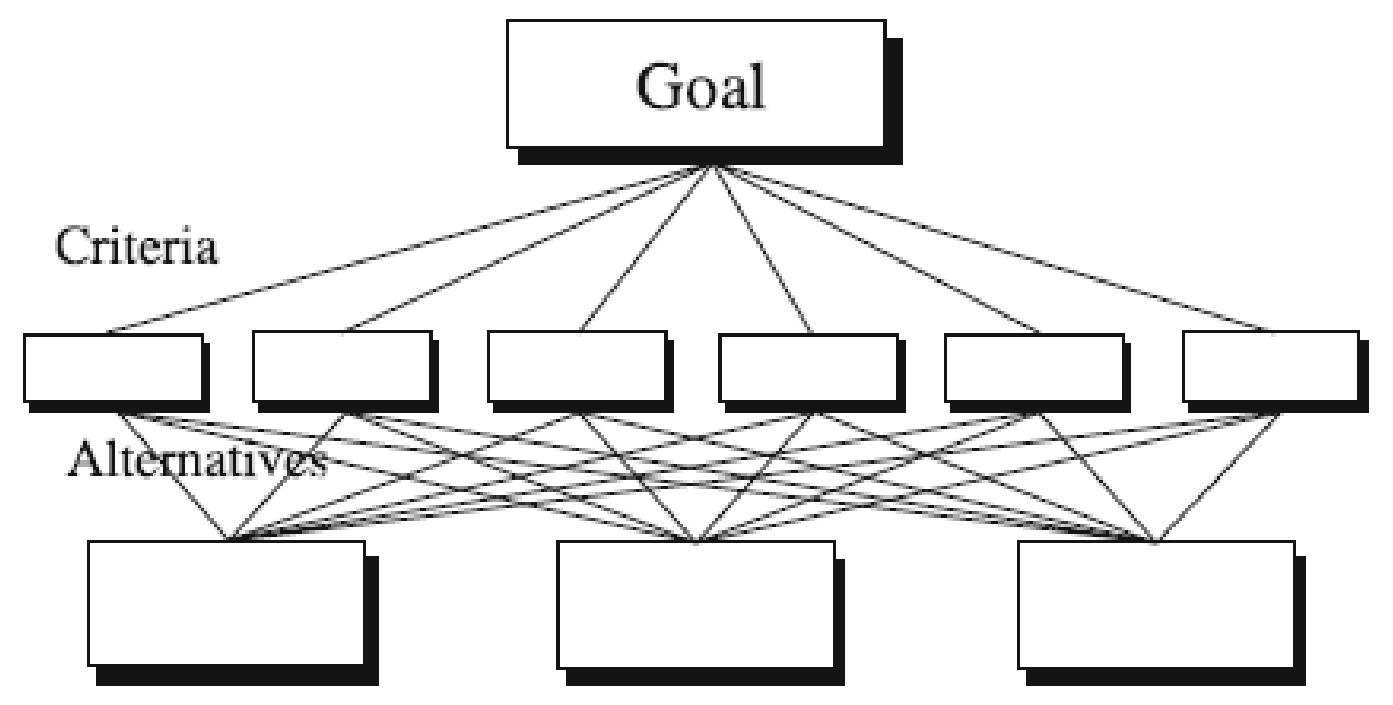

Gambar 1 Struktur Hirarki Sederhana

Pemilihan alternatif berdasarkan kriteria tertentu dapat terjadi secara rasional maupun intuitif yang tidak konsisten (Saaty \& Vargas, 2012, p.1). AHP merupakan metode yang dapat digunakan untuk mengembangkan pengukuran dalam bentuk pengaruh fisik dan sosial untuk menggambarkan persoalan yang ada (Saaty \& Vargas, 2012, p.3). Menurut Alonso \& Lamata (2006) seperti dikutip oleh Qubaisi et al. (2016), AHP memiliki penilaian sistematis bawaan untuk konsistensi penilaian. Skala fundamental yang telah divalidasi keefektivitasannya dalam banyak 
Nama Penulis satu, dua

Jurnal Teknologi Vol xx No xx (20xx ) 8-13

penerapan nyata dan diuji secara teoritis digunakan untuk menentukan intensitas penilaian pada elemen AHP pada tabel 1 .

Tabel 1 Skala Fundamental

\begin{tabular}{|c|c|c|}
\hline $\begin{array}{l}\text { Intensity of } \\
\text { Importance }\end{array}$ & Definition & Explanation \\
\hline 1 & Equal importance & Two activities contribute equally to the objective \\
\hline 2 & Weak & \\
\hline 3 & Moderate importance & Experience and judgement slightly favor one activity over another \\
\hline 4 & Moderate plus & \\
\hline 5 & Strong importance & Experience and judgement strongly favor one activity over another \\
\hline 6 & Strong plus & \\
\hline 7 & $\begin{array}{l}\text { Very strong or demonstrated } \\
\text { importance }\end{array}$ & $\begin{array}{l}\text { An activity is favored very strongly over another; its dominance demonstrated in } \\
\text { practice }\end{array}$ \\
\hline 8 & Very, very strong & \\
\hline 9 & Extreme importance & $\begin{array}{l}\text { The evidence favoring one activity over another is of the highest possible order of } \\
\text { affirmation }\end{array}$ \\
\hline
\end{tabular}

Menurut Suryadi dan Ramdhani (2010) yang dikutip oleh Saragih (2013), perlu adanya pemeriksaan terhadap konsistensi hirarki dengan cara melihat indeks konsistensi dimana rasio konsistensi yang diterima lebih kecil sama dengan $10 \%$, dengan rumus sebagai berikut:

$\mathrm{CI}=(\lambda$ maksimum $-\mathrm{n}) /(\mathrm{n}-1)$

$\mathrm{CR}=\mathrm{CI} / \mathrm{RI}$

Dimana:

$\mathrm{CI}=$ indeks konsistensi

$\lambda$ maksimum $=$ Nilai eigen terbesar dari matriks berordo $n$

$\lambda$ maksimum diperoleh dengan cara menjumlahkan hasil perkalian jumlah kolom dengan eigen vektor utama. Apabila $\mathrm{CI}=0$, berarti matriks konsisten.

Berikut adalah tabel nilai RI (Nilai Pembangkit Random) berdasarkan ordo n pada tabel 2 :

Tabel 2 Nilai RI Berdasarkan Ordo n

\begin{tabular}{cc}
\hline $\mathrm{N}$ & $\mathrm{RI}$ \\
\hline 1 & 0.00 \\
2 & 0.00 \\
3 & 0.58 \\
4 & 0.90 \\
5 & 1.12 \\
\hline
\end{tabular}




\begin{tabular}{cc}
\hline $\mathrm{N}$ & $\mathrm{R}$ \\
\hline 6 & 1.24 \\
7 & 1.32 \\
8 & 1.41 \\
9 & 1.45 \\
10 & 1.49 \\
11 & 1.51 \\
12 & 1.58 \\
\hline
\end{tabular}

Langkah-langkah yang perlu dilakukan untuk membuat kerangka hirarki (Saaty \& Vargas, 2012, p.9-10), yaitu:

(1) Menentukan tujuan akhir, (2) Menentukan tujuan penunjang bagi tujuan akhir, (3) Menentukan kriteria yang dapat memenuhi tujuan penunjang dan tujuan akhir, (4) Menentukan kriteria penunjang bagi masing-masing kriteria, (5) Menentukan responden yang terlibat, (6) Menentukan tujuan responden, (7) Menentukan kebijakan responden, (8) Menentukan pilihan/ hasil, (9) Memilih hasil terbaik dengan membandingkan rasio manfaat yang diterima dari setiap alternatif, (10) Melakukan analisa manfaat/biaya.

\section{Metode Penelitian}

Tahap awal yang dilakukan peneliti adalah melakukan survei pendahuluan untuk mengetahui kepuasan mahasiswa dengan laptop yang dimilikinya dan kesulitan mahasiswa untuk menentukan jenis laptop yang harus dibeli sebagai daily driver. Melalui survei pendahuluan ini diperoleh latar belakang masalah tentang AHP yang merupakan salah satu alat untuk mengambil keputusan yang dapat digunakan pada mahasiswa dalam menentukan laptop yang sesuai dengan kebutuhan perkuliahan mereka. Tahap selanjutnya peneliti mencari penelitian terdahulu yang menggunakan metode AHP sebagai alat dalam pengambilan keputusan. Setelah mempelajari penelitian terdahulu terkait AHP, peneliti memperoleh rumusan masalah, tujuan dan manfaat dari penelitian ini. Peneliti pun menetapkan batasanbatasan masalah untuk penelitian ini dan mencari studi literatur mengenai penggunaan AHP sebagai alat pengambilan keputusan dalam berbagai bidang.

Pengumpulan data yang dilakukan peneliti adalah membagikan lembar perbandingan sebagai data masukan untuk diolah AHP kepada 30 mahasiswa yang berkuliah di Jakarta Utara. Pengolahan data yang dilakukan peneliti adalah mengubah lembar perbandingan yang telah diisi menjadi matriks perbandingan untuk memperoleh bobot prioritas pemilihan, serta menghitung rasio konsistensi dari matriks perbandingan yang telah dibuat. Rasio konsistensi yang nilainya lebih kecil sama dengan 0,1 dinyatakan konsisten dan hasil perhitungan bobot prioritas dari matriks perbandingan dapat digunakan, sedangkan rasio konsistensi yang nilainya lebih dari 0,1 harus dilakukan pengisian ulang matriks perbandingan hingga hasil rasio konsistensi lebih kecil sama dengan 0,1 . Setelah seluruh matriks perbandingan memiliki rasio konsistensi lebih kecil sama dengan 0,1 maka peneliti menghitung bobot prioritas secara keseluruhan dengan mengambil nilai rata-rata.

Analisa yang dilakukan peneliti adalah menentukan hasil perhitungan rata-rata bobot prioritas dari 30 mahasiswa menjadi pengambilan keputusan terhadap salah satu alternatif yang telah ditentukan. Setelah memperoleh hasil dari pengambilan keputusan, peneliti membuat kesimpulan dari penelitian saat ini dan saran yang dapat dilakukan penelitian selanjutnya.

\section{Hasil dan Pembahasan}

Kriteria yang diperlukan untuk mencapai tujuan pemilihan alternatif laptop berdasarkan para ahli pada penelitian Sunarsa \& Handayani (2016) adalah Merek, Processor, VGA, RAM, Kapasitas HDD, Keunggulan, dan Harga. Spesifikasi dari tiga alternatif laptop dapat dilihat pada Tabel 3 : 
Nama Penulis satu, dua

Jurnal Teknologi Vol xx No xx (20xx ) 8-13

Tabel 3 Spesifikasi Tiga Alternatif Laptop.

\begin{tabular}{|c|c|c|c|}
\hline Merek Laptop & ASUS A456UR & ACER Aspire E5-475G-52MT & Lenovo Idepad 310 \\
\hline Processor & Intel Core i5/2.5-3.10 GHz & Intel Core i $5 / 2.5-3.10 \mathrm{GHz}$ & Intel Core i5/2.5-3.10 GHz \\
\hline VGA & Nvidia GT930MX 2GB & Nvidia GT940MX 2GB & Nvidia GT920MX 2GB \\
\hline RAM & $4 \mathrm{~GB}$ & $4 \mathrm{~GB}$ & $4 \mathrm{~GB}$ \\
\hline HDD & $1 \mathrm{~TB}$ & $1 \mathrm{~TB}$ & $1 \mathrm{~TB}$ \\
\hline Ukuran Layar & $14 ”$ & $14 "$ & $14 "$ \\
\hline Keunggulan & $\mathrm{DVD} / \mathrm{BT} / \mathrm{CAM}$ & $\mathrm{DVD} / \mathrm{BT} / \mathrm{CAM}$ & DVD/BT/CAM \\
\hline Harga & Rp 7.312.000,- & Rp 7.495.000,- & Rp 7.395.000,- \\
\hline
\end{tabular}

Data masukan bagi AHP didapat dari pengisian kuisioner oleh 30 mahasiswa yang sedang berkuliah di universitas di Jakarta Utara. Matriks perbandingan antara kriteria dengan kriteria, dan alternatif dengan alternatif pada masingmasing kriteria dari 30 mahasiswa dihitung menggunakan template pengerjaan AHP pada software Microsoft Excel 2016 yang dibentuk oleh peneliti. Bobot prioritas kriteria dari perbandingan kriteria dengan kriteria dari 30 mahasiswa pada tabel 4.

Tabel 4 Bobot Prioritas Kriteria

\begin{tabular}{lrc}
\hline \multicolumn{1}{c}{ Kriteria } & Persentase & Peringkat \\
\hline Merek & $6.15 \%$ & 7 \\
Processor & $19.64 \%$ & 2 \\
VGA & $15.32 \%$ & 4 \\
RAM & $16.89 \%$ & 3 \\
Kapasitas HDD & $12.97 \%$ & 5 \\
Keunggulan & $9.12 \%$ & 6 \\
Harga & $19.90 \%$ & 1 \\
Jumlah & $100.00 \%$ & \\
\hline
\end{tabular}

Bobot prioritas total dari setiap alternatif yang didapat dari perbandingan alternatif dengan alternatif pada masingmasing kriteria yang telah dikalikan dengan bobot prioritas kriteria dari 30 mahasiswa pada tabel 5.

Tabel 5 Bobot Prioritas Alternatif

\begin{tabular}{lrc}
\hline \multicolumn{1}{r}{ Alternatif } & Persentase & Keputusan \\
\hline Asus & $50.25 \%$ & Terpilih \\
Acer & $27.86 \%$ & \\
Lenovo & $21.89 \%$ & \\
\hline
\end{tabular}

Hasil pengolahan data dari matriks perbandingan antara kriteria dengan kriteria menunjukkan bobot prioritas kriteria tertinggi dengan persentase sebesar 19,9\% yaitu, harga. Kriteria kedua tertinggi dengan nilai 19,64\% yaitu, processor. Kriteria ketiga tertinggi dengan nilai 16,89\%. Kriteria dengan urutan prioritas keempat hingga terakhir diperoleh oleh kriteria VGA, kapasitas HDD, keunggulan, dan merek dengan nilai sebesar 15,32\%, 12,97\%, 9,12\%, dan 6,15\%. Hasil pengolahan data bobot prioritas total dari setiap alternatif yang didapat dari perbandingan alternatif dengan alternatif pada masing-masing kriteria yang telah dikalikan dengan bobot prioritas kriteria dari 30 mahasiswa menunjukkan alternatif ASUS memperoleh persentase tertinggi sebesar 50,25\%, alternatif ACER memperoleh persentase sebesar 27,86\%, alternatif LENOVO memperoleh persentase terendah sebesar 21,89\%. Pengambilan keputusan alternatif berdasarkan bobot prioritas dengan persentase tertinggi, yaitu alternatif ASUS sebesar 50,25\%.

\section{Kesimpulan}

Bobot prioritas dari setiap kriteria yang telah ditentukan, yaitu merek $(6,15 \%)$, processor $(19,64 \%)$, VGA $(15,32 \%)$, RAM (16,89\%), kapasitas HDD (12,97\%), keunggulan (9,12\%), dan harga (19,9\%). Bobot prioritas total dari setiap alternatif setelah dikalikan dengan bobot kriteria, yaitu ASUS (50,25\%), ACER (27,86\%), dan LENOVO (21,89\%). Hasil pengambilan keputusan pemilihan laptop menggunakan metode AHP, yaitu alternatif ASUS dengan tipe A456UR terpilih menjadi daily driver mahasiswa. Beberapa saran untuk mengembangkan penelitian ini adalah 
memilih laptop-laptop terbaru yang sesuai dengan spesifikasi software yang digunakan selama kegiatan perkuliahan sebagai alternatif hirarki berikutnya serta membandingkan software $\neg$-software yang dapat digunakan untuk praktikum mata kuliah tertentu sebagai alternatif hirarki berikutnya..

\section{Daftar Rujukan}

[1] Gabriella, Petrina \& Tannady, Hendy. (2019). Pengaruh Motivasi dan Disiplin Kerja Terhadap Kinerja Guru di SMAN 8 Bekasi. Seminar Nasional Sains \& Teknologi Informasi (SENSASI), hal. 121-124.

[2] Patterson, R. W., \& Patterson, R. M. (2017). Computers and Productivity: Evidence from Laptop Use in the College Classroom. Economics of Education Review. Vol. 57, hal. 66-79.

[3] Pratama, Bagaskara., Tannady, Hendy \& Jodiawan, Panca. (2017). ANALISIS PENGARUH KUALITAS TERHADAP KEPUASAN PELANGGAN (STUDI KASUS DI NN LAUNDY, JAKARTA SELATAN). Jurnal Teknik dan Ilmu Komputer. Vol. 6, No. 24.

[4] Qubaisi, A. A., Badri, M., Mohaidat, J., Dhaheri, H. A., Yang, G., Rashedi, A. A., \& Greer, K. (2016). An analytic hierarchy process for school quality and inspection Model development and application. International Journal of Educational Management. Vol. 30(3): 437-459.

[5] Rahayu, Mieke., Rasid, Fahmi \& Tannady, Hendy. (2019). The Effect of Career Training and Development on Job Satisfaction and its Implications for the Organizational Commitment of Regional Secretariat (SETDA) Employees of Jambi Provincial Government. International Review of Management and Marketing. Vol 9, No. 1, hal. 79-89.

[6] Rahayu, Mieke., Rasid, Fahmi \& Tannady, Hendy. (2018). Effects of Self Efficacy, Job Satisfaction, and Work Culture Toward Performance of Telemarketing Staff in Banking Sector. South East Asia Journal of Contemporary Business, Economics and Law. Vol 16, No. 5, hal. 47-52.

[7] Rosta, Jevi \& Tannady, Hendy. (2013). Aplikasi AHP Dalam Menentukan Kandidat Gubernur DKI Jakarta 2012-2017. ComTech: Computer, Mathematics and Engineering Applications. Vol. 4, No. 1, hal. 394-406.

\section{PETUNJUK PENULISAN REFERENSI}

1. Referensi yang berasal dari buku

Aturan penulisan: Author, Initials/First name., Year. Title of book. Edition. Place of publication: Publisher.

Contoh:

Redman, P., 2006. Good essay writing: a social sciences guide. 3rd ed. London: Open University in assoc. with Sage.

2. Referensi yang berasal dari jurnal

Aturan penulisan: Author, Initials., Year. Title of article. Full Title of Journal, Volume number (Issue/Part number), Page numbers.

Contoh:

Boughton, J.M., 2002. The Bretton Woods proposal: an in depth look. Political Science Quarterly, 42 (6), pp.56478. 